\title{
Potensi Antibakteri Isolat Jamur Endofit dari Daun Kelor (Moringa oleifera Lam.)
}

\author{
Sukriani Kursia*, Rahmad Aksa, Maria Magdalena Nolo
}

Sekolah Tinggi Ilmu Farmasi Makassar, Jl. Perintis Kemerdekaan KM. 13,7 Daya, Makassar 90241

\begin{abstract}
Abstrak
Kelor (Moringa oleifera Lam.) mengandung metabolit sekunder dan berkhasiat sebagai antibakteri. Metabolit sekunder tanaman kelor dapat diperoleh dari fungi endofit yang berasosiasi dalam jaringan tanaman. Tujuan penelitian ini ialah menentukan potensi antibakteri isolat fungi endofit daun kelor. Isolasi fungi endofit daun kelor diperoleh sebanyak 3 isolat yaitu isolat M2NG, M2NB, dan M2NW. Penelitian ini meliputi uji antagonis, fermentasi, ekstraksi dan uji aktivitas menggunakan metode difusi agar. Hasil uji antagonis menunjukkan isolat M2NG paling aktif menghambat pertumbuhan bakteri E. coli, S. aureus, P. aureginosa, dan S. typhi. Ekstrak etil asetat fermentat isolat hijau konsentrasi $4 \%$ memiliki aktivitas menghambat bakteri uji dengan diameter zona hambat tertinggi yaitu $17,94 \mathrm{~mm}$ untuk bakteri $E$. coli dan $16,85 \mathrm{~mm}$ untuk bakteri $S$. aureus. Identifikasi metabolit sekunder ekstrak etil asetat mengandung flavonoid, alkaloid dan polifenol. Hasil penelitian menunjukkan bahwa isolat fungi endofit daun kelor memiliki aktivitas antibakteri spektrum luas.
\end{abstract}

Kata kunci: Moringa oleifera, isolat, fungi endofit, antibakteri

\section{Pendahuluan}

Tanaman kelor (Moringa oleifera Lam.) merupakan tanaman obat yang dapat mengobati gangguan jantung, antioksidan, antibakteri, antijamur, antikolesterol, dan antiinflamasi [1]. Daun Kelor (Moringa oleifera Lam.) dapat digunakan sebagai antimikroba, antibakteri, penyakit infeksi, mencegah ulkus, peradangan, nyeri, meningkatkan kekebalan tubuh, mempercepat proses penyembuhan luka [2].

Ekstrak etanol daun kelor dapat menghambat pertumbuhan bakteri S. aureus, S. typhi, P. aureginosa, dan E. coli. Ekstrak daun kelor konsentrasi 80\% memilki diameter zona hambat tertinggi yaitu $21,50 \mathrm{~mm}$ pada bakteri $S$. aureus dan $24,00 \mathrm{~mm}$ pada bakteri E. coli. Hal ini diduga ekstrak daun kelor mengandung metabolit sekunder seperti flavonoid, alkaloid dan fenol $[3,4]$. Pengambilan senyawa bioaktif secara langsung dari daun kelor membutuhkan biomassa yang banyak. Pengambilan senyawa bioaktif dapat diefisienkan dengan menggunakan fungi endofit.

Fungi endofit merupakan mikroorganisme yang mempunyai habitat hidup di dalam organ tanaman dalam kurun waktu tertentu, dapat berkolonisasi di dalam jaringan tanaman tanpa merugikan tanaman inangnya. Kemampuan mikroba endofit memproduksi metabolit sekunder sesuai dengan tanaman inangnya merupakan peluang yang sangat besar dan dapat diandalkan untuk memproduksi senyawa dari mikroba endofit yang diisolasi dari tanaman inangnya [5]. Oleh karena itu, isolasi fungi endofit dari daun kelor (Moringa oleifera Lam.) perlu dilakukan untuk menghasilkan senyawa metabolit sekunder yang memiliki aktivitas sebagai antibakteri

\section{Bahan dan Metode}

\subsection{Isolasi dan Pemurnian Jamur Endofit}

Sampel daun kelor (Moringa oleifera Lam.) dicuci dengan air mengalir untuk menghilangkan kotoran yang menempel dan dipotong $\pm 1 \mathrm{~cm}$. Sterilisasi permukaan dilakukan dengan cara direndam dalam etanol $70 \%$ selama 30 detik kemudian direndam dalam larutan natrium hipoklorit $(\mathrm{NaOCl}) 5,25 \%$ selama 30 detik. Sampel daun dibilas dengan air suling steril sebanyak 3 kali kemudian dikeringkan. Potongan sampel yang telah kering ditanam pada media PDAC dan diinkubasi pada suhu kamar $\left(25^{\circ} \mathrm{C}\right)$ selama 7 hari. Pemurnian fungi endofit dilakukan dengan pemindahan koloni ke cawan petri lain yang berisi medium PDAC, kemudian

\footnotetext{
*Email : sukriani.winie@yahoo.com
} 
diinkubasi pada suhu kamar selama 3-5 hari. Jamur endofit yang telah diinkubasi kemudian diidentifikasi berdasarkan ciri-ciri makroskopik secara langsung langsung dengan melihat bentuk dan warna koloni jamur endofit.

\subsection{Pengujian Antagonis Jamur Endofit}

Isolat jamur endofit murni yang telah ditumbuhkan pada medium PDAC kemudian diambil 1 potong dan diletakkan pada permukaan media NA yang telah diinokulasikan dengan bakteri uji seperti E. coli, $S$. aureus, S. typhi, dan P. aureginosa. Cawan berisi jamur endofit dan bakteri uji diinkubasi selama 1x24 jam pada suhu $37^{\circ} \mathrm{C}$. Jamur endofit yang positif dapat menghambat bakteri uji akan digunakan untuk uji selanjutnya.

\subsection{Fermentasi Jamur Endofit}

Isolat yang menunjukkan zona hambat tertinggi pada uji antagonis selanjutnya difermentasi menggunakan metode goyang. Fermentasi dilakukan dengan cara menggambil 1 ose isolat yang telah dimurnikan lalu dimasukkan ke dalam erlenmeyer 250 $\mathrm{ml}$ yang mengandung $100 \mathrm{ml}$ medium cair PDY lalu dilakukan fermentasi dengan menggunakan orbital shaker pada kecepatan 130 rpm, selama 14 hari.

\subsection{Ekstraksi Senyawa Metabolit}

Setelah proses fermentasi selama 14 hari, miselia dipisahkan dari cairan fermentasi menggunakan kertas saring. Ekstraksi dilakukan dengan metode ekstraksi cair-cair menggunakan corong pisah dengan pelarut etil asetat. Cairan fermentasi diekstrak dengan perbandingan 1:1. Lapisan etil asetat yang berada diatas dikeluarkan dan lapisan bawah ditambahkan lagi pelarut etil asetat dengan perbandingan 1:1. Proses ini dilakukan sebanyak 3 kali. Ekstrak yang diperoleh disimpan untuk digunakan pada uji selanjutnya.

\subsection{Pengujian Aktivitas Antibakteri}

Uji aktivitas antibakteri menggunakan metode difusi agar dengan medium MHA (Muller Hinton Agar). Kertas cakram kosong ditetesi ekstrak sebanyak $20 \mu \mathrm{L}$ dengan konsentrasi $1 \%, 2 \%, 4 \%$, lalu dibiarkan sampai semua pelarut menguap sempurna. Kertas cakram yang mengandung ekstrak, kontrol $(+)$, dan kontrol (-) diletakkan pada permukaan media yang telah diinokulasikan dengan bakteri uji. Untuk kontrol positif digunakan tetrasiklin $30 \mu \mathrm{g}$ dan kontrol negatif DMSO $10 \%$. Selanjutnya diinkubasi selama $1 \times 24$ jam pada suhu $37^{\circ} \mathrm{C}$, lalu diamati zona hambat. Zona hambat yang terbentuk diukur diameternya menggunakan jangka sorong.

\subsection{Pengujian Metabolit Sekunder}

Alkaloid

Ekstrak etil asetat diambil secukupnya, lalu ditempatkan pada plat tetes dan masing-masing ditambahkan pereaksi Dragendorff, Wagner dan Mayer. Endapan yang terbentuk menunjukkan bahwa ekstrak tersebut mengandung alkaloid. Hasil positif Dragendorff memberikan endapan jingga, pereaksi Wagner memberikan endapan coklat, dan pereaksi Mayer memberikan endapan putih.

\section{Flavonoid}

Ekstrak etil asetat diambil secukupnya, lalu ditempatkan pada plat tetes dilarutkan dengan metanol dan ditambahkan beberapa tetes $\mathrm{HCl}$ pekat dan serbuk Mg. Hasil positif menunjukkan terbentuknya warna merah jingga.

\section{Polifenol}

Ekstrak etil asetat diambil lalu ditempatkan pada plat tetes, kemudian ditambahkan pereaksi $\mathrm{FeCl}_{3} 1 \%$. Hasil positif menunjukkan terbentuknya warna hijau kehitaman

\section{Hasil dan Pembahasan}

Penelitian ini dilakukan untuk mengetahui potensi antibakteri isolat jamur endofit daun kelor (M. oleifera Lam.). Hasil isolasi fungi endofit daun kelor diperoleh 3 isolat yaitu M2NG, M2NB, dan M2NW. Satu jaringan hidup suatu tumbuhan dapat menjadi inang tempat tumbuh lebih dari satu jenis jamur endofit [6]. Kandungan jenis endofit yang berbeda ini merupakan mekanisme adaptasi dari endofit terhadap mikroekologi dan kondisi fisiologis yang spesifik dari masing-masing tumbuhan inang.

Tahap awal dilakukan setelah diperoleh isolat yaitu uji antagonis. Pengujian antagonis bertujuan untuk mengetahui aktivitas langsung terhadap bakteri uji dan menyeleksi isolat yang memiliki aktivitas antibakteri yang nantinya akan dilanjutkan ke tahap fermentasi. Isolat fungi endofit dilakukan uji antagonis dengan cara meletakkan potongan isolat pada cawan petri yang telah mengandung bakteri uji. Hasil pengujian antagonis memberikan gambaran bahwa isolat yang paling aktif dalam menghambat 4 bakteri uji yaitu isolat M2NG.

Selanjutnya dilakukan proses fermentasi terhadap isolat M2NG. Fermentasi adalah proses penguraian produk metabolit sekunder oleh mikroorganisme. Fermentasi yang digunakan yaitu sistem batch. Sistem batch yaitu sistem yang paling sederhana dan sering digunakan di laboratorium untuk mendapatkan produk sel atau metabolitnya. Fermentasi sistem batch adalah sistem tertutup, artinya semua nutrisi yang dibutuhkan mikroba selama proses pertumbuhan dan pembentukan 
produk berada didalam 1 fermentor. Jadi tidak ada penambahan bahan atau pengambilan hasil selama proses fermentasi. Keuntungan sistem ini adalah mudah, sederhana, dan kecil kemungkinan adanya kontaminasi [7].

Tabel 1. Karakteristik morfologi koloni fungi endofit daun kelor (M. oleifera Lam.)

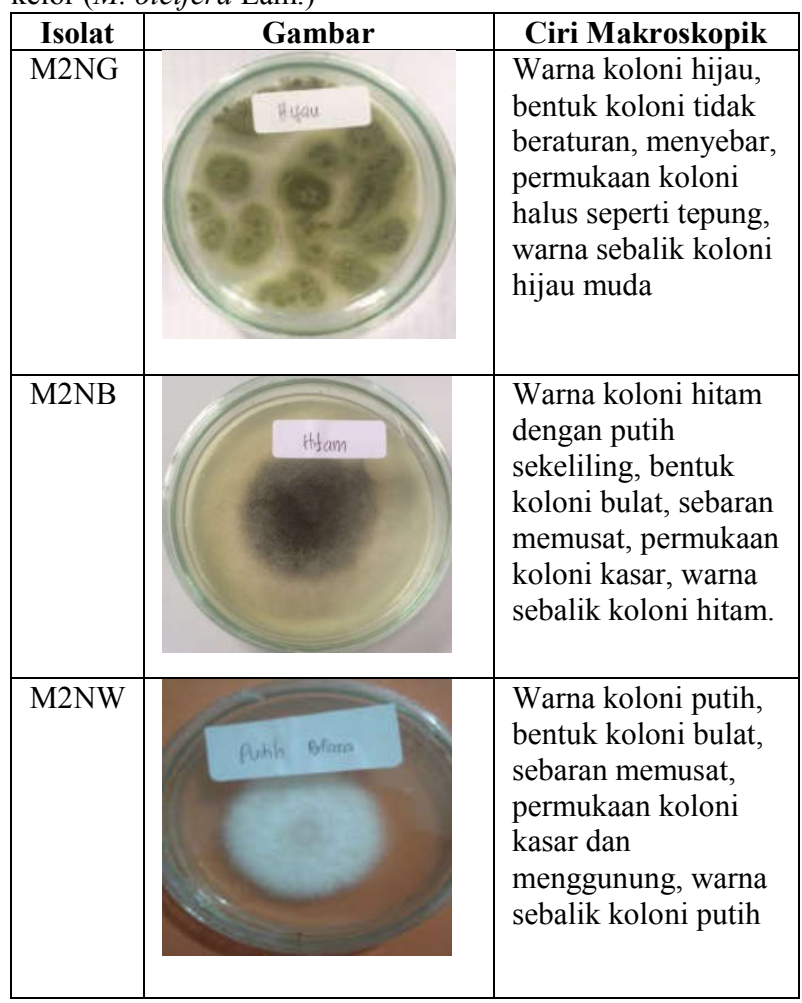

Proses fermentasi selama 14 hari, untuk memperoleh metabolit sekunder. Pembentukan metabolit sekunder terjadi pada fase stasioner yaitu fase ketika laju pembelahan sel dan laju kematian mikroba mencapai kesetimbangan, dimulai saat zat gizi dalam medium pertumbuhan mikroorganisme telah habis [8]. Keterbatasan zat gizi dalam medium dapat menyebabkan terakumulasi enzim metabolit sekunder dan gen-gen metabolit sekunder, diduga meningkatkan produksi metabolit sekunder. Fermentat diekstraksi dengan pelarut etil asetat menghasilkan ekstrak etil asetat sebanyak $300 \mathrm{mg}$.
Aktivitas antimikroba ditentukan dengan area jernih yang mengindikasikan adanya hambatan terhadap pertumbuhan mikroorganisme pada permukaan media agar [9]. Uji aktivitas antibakteri ektrak etil asetat terhadap bakteri $S$. aureus, E. coli, $P$. aureginosa, dan $S$. typhi, digunakan ekstrak dengan 3 konsentrasi yaitu $1 \%$, $2 \%$, dan $4 \%$ serta kontrol (-) dan kontrol $(+)$ yaitu Tetrasiklin. Hasil pengujian potensi antibakteri menunjukkan bahwa isolate M2NG paling aktif terhadap bakteri Escherichia coli pada konsentrasi 4 \% (Tabel 3)

Tabel 2. Hasil uji antagonis isolat fungi endofit

\begin{tabular}{lcccc}
\hline Bakteri & \multicolumn{3}{c}{ Isolat Fungi } & Tetrasiklin \\
\cline { 2 - 4 } & M2NG & M2NB & M2NW & \\
\hline S. aureus & ++ & ++ & + & ++ \\
E. coli & ++ & + & + & ++ \\
P. aureginosa & ++ & ++ & ++ & ++ \\
S. typhi & ++ & + & + & ++ \\
\hline
\end{tabular}

Ket: Diameter zona hambat : $++(>20 \mathrm{~mm}),+(<20 \mathrm{~mm}),-(0)$

Berdasarkan hasil yang didapatkan pada uji aktivitas antibakteri, ekstrak etil asetat fungi endofit bersifat antimikroba spektrum luas karena mampu menghambat bakteri Gram positif yaitu $S$. aureus dan bakteri Gram negatif yaitu E. coli, S. typhi, $P$. aureginosa. Salah satu faktor yang dapat mempengaruhi penghambatan mikroorganisme adalah konsentrasi zat aktif. Semakin besar konsentrasi zat yang diberikan maka semakin banyak sel-sel mikroorganisme yang mati. Sesuai dengan hal tersebut, dari hasil penelitian diperoleh bahwa semakin tinggi konsentrasi ekstrak maka semakin besar diameter zona hambat yang terbentuk.

Adanya aktivitas antibakteri ekstrak etil asetat fungi endofit dikarenakan ekstrak memiliki kandungan metabolit sekunder yang berpotensi sebagai antibakteri. Penentuan golongan senyawa metabolit sekunder menunjukkan hasil isolat fungi endofit hijau dari daun kelor mengandung alkaloid, flavonoid, dan polifenol (Tabel 4.) Penelitian sebelumnya mempelihatkan bahwa ekstrak daun kelor mengandung metabolit sekunder alkaloid, flavonoid dan polifenol [10]. Alkaloid dapat mengganggu komponen penyusun dinding sel (peptidoglikan) pada sel bakteri, sehingga lapisan dinding sel bakteri tidak terbentuk secara utuh dan menyebabkan kematian sel bakteri [11].

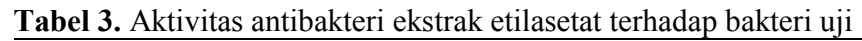

\begin{tabular}{lccccc}
\hline \multirow{2}{*}{ Bakteri Uji } & \multicolumn{5}{c}{ Diameter Zona Hambat (mm) } \\
\cline { 2 - 6 } & $\mathbf{1 \%}$ & $\mathbf{2 \%}$ & $\mathbf{3 \%}$ & K+ & K- \\
\hline Eschericia coli & $10.44 \pm 0.31$ & $14.78 \pm 0.79$ & $17.94 \pm 0.63$ & $22.53 \pm 0.21$ & 6 \\
Staphylococcus aureus & $9.14 \pm 0.22$ & $13.25 \pm 0.18$ & $16.88 \pm 0.11$ & $24.74 \pm 0.22$ & 6 \\
Pseudomonas aureginosa & $9.27 \pm 0.19$ & $12.14 \pm 0.27$ & $14.05 \pm 0.6$ & $20.22 \pm 0.16$ & 6 \\
Salmonella typhi & $9.52 \pm 0.17$ & $12.28 \pm 0.05$ & $14.38 \pm 0.24$ & $17.45 \pm 0.2$ & 6 \\
\hline
\end{tabular}


Tabel 4. Hasil uji kandungan metabolit sekunder ekstrak etilasetat daun kelor

\begin{tabular}{lccc}
\hline Uji Golongan Senyawa & Hasil Uji [12] & Hasil Penelitian & Keterangan \\
\hline Alkaloid (Dragendorff) & Endapan jingga & Endapan jingga & + \\
Alkaloid (Wagner) & Endapan coklat & Endapan coklat & + \\
Alkaloid (Mayer) & Endapan putih & Endapan putih & + \\
Flavonoid & Merah jingga & Merah jingga & + \\
Polifenol & Hijau kehitaman & Hijau kehitaman & + \\
\hline
\end{tabular}

Flavonoid sebagai antibakteri bekerja membentuk senyawa kompleks dengan protein ekstraseluler sehingga dapat merusak membran sel bakteri diikuti keluarnya senyawa intraseluler. Senyawa polifenol bekerja menghambat enzim reverse trasnkripsi dan DNA topoisomerase sehingga sel bakteri tidak terbentuk.

\section{Kesimpulan}

Isolat jamur endofit dari ekstrak daun kelor (Moringa oleifera Lam. yang paling berpotensi sebagai antibakteri spektrum luas yaitu isolat M2NG.

\section{Daftar Pustaka}

1. Gaikwad SB, Mohan GK, Reddy KJ. Moringa oleifera Leaves: Immunomodulation In Wistar Albino Rats. Int J Pharm Pharm Sci, 2011, Vol 3, Suppl 5; 426-430

2. Anwar F, Latif S, Ashraf M, Gilani AH. Moringa oleifera: a food plant with multiple medicinal uses. Phytother Res, 2007, 21(1); 17-25.

3. Dima LLR, Lolo WA, Fatimawali. Uji Aktivitas Antibakteri Ekstrak Daun Kelor (Moringa oleifera L.) Terhadap Bakteri Escherichia coli dan Staphylococcus aureus: PHARMACON, 2016, Vol 5(2)

4. Vinoth B, Manivasagaperumal R, Balamurugan $\mathrm{S}$. Phytochemical analysis and antibacterial activity of Moringa oleifera Lam. Int. J. Res. Biol. Sci, 2012, 2; 98102.
5. Zeng PY, Wu JG, Liao LM, Chen TQ, Wu JZ Wong KH. In vitro antioxidant activities of endophytic fungi isolated from the liverwort Scapania verrucosa. Genet. Mol. Res., 2011, 10 (4);3169-3179.

6. Noverita, Fitria D, Sinaga E. Isolasi dan Uji Aktivitas Antibakteri Jamur Endofit dari Daun dan Rimpang Zingiber ottensii Val. Jurnal Farmasi Indonesia, 2009, 4(4);171 -176

7. Djide NM, Sartini. Dasar-dasar Mikrobiologi Farmasi. Makassar: Lembaga Penerbitan Unhas, 2008.

8. Kumala S. 2014, Mikroba Endofit, ISFI Penerbitan: Jakarta Barat.

9. Alimuddin, A. 2006, Mikrobiologi Dasar II, Jilid II, Badan Penerbit Universitas Negeri Makassar, Makassar

10. Abalaka ME, Daniyan SY, Oyeleke SB, Adeyemo SO. Antibacterial Evaluation of Moringa Oleifera Leaf Extracts on Selected Bacterial Pathogens. $J$ of Microbiology Res. ,2011, 1(1); 1-4.

11. Fadlila WN, Yuliawati KM, Livia S. Identifikasi Senyawa Aktif Antibakteri dengan Metode Bioautografi terhadap Ekstrak Etanol tangkai Daun Talas (Colocasia esculenta (L.) Schott), Prosiding Farmasi Spesia: Seminar Penelitian Sivitas Akademika Unisba (Kesehatan dan Farmasi), ISSN 2460-6472

12. Nopiana. Pengaruh Pemberian Ekstrak Etanol 70\% Daun Kelor (Moringa oleifera Lam.) Terhadap Tekanan Darah Tikus Putih Betina Anemia. Jakarta: Universitas Indonesia, 2013. 